


\title{
Fashion and Neoliberalism: How Self-Commodification Becomes Integral to the Entrepreneurial Ethical Fashion Designer
}

\author{
Vigdís Póra Másdóttir
}

The object under analysis is more than just a shrug on a hanger. It is a sustainable fashion item, an attempt by a fashion design student to impress and make a statement. What that statement is and how it is made remains the question. Is an object simply the statement or is the artist behind it the actual statement? Arna Lísa is a young fashion design student from Iceland at Parsons School of Fashion and Design in New York. Through my conversations with her, I set out to understand the precariousness of being an up and coming fashion designer in a cut-throat environment. The question at the back of my mind remained one of the concepts of value and taste. Who demarcates the borders of taste and value and how can we see the underlying power relations at play?

The fashion industry serves as a notable backdrop for this as the border between sellable designs and artistry is ever changing. This leads us as well to the concept of selfcommodification of the artist as a brand, where the artist gains value and representation and where the boundaries of class and taste each artist represents, collide. This essay will engage with the neoliberal tendencies that the fashion and art world have come to be known for as well as how ethical fashion plays into these capitalist tendencies, which also serve as a source of constant source of anxiety for the artist.

\section{Is a shrug ever just a shrug?}

The shrug is made out of a piece of fabric called muslin, which generally serves as the preliminary sketching and trial tool for the designer to test the pieces he later plans on making out of another more expensive material. In the end, it gets thrown into the trash, where Arna Lísa found most of her pieces of material, as well as collecting some from the floor to create a zero-waste fashion statement. The piece in itself is also part of a certain movement in ethical fashion. The precariousness of the fashion industry can also be shown in the object. For instance, the border between the 'ethical sell' and the marketable, 'mass-produced sell'. Arna Lísa expressed the anxiety behind creating a fashionable piece that also has a certain practicality behind it, while also being a sustainable piece of clothing. The shrug can, therefore, represent the collision between the capitalist influence of the market and the creative process of the art world.

\section{Zero-waste and Ethical Fashion}

Ethical fashion is still a relatively small segment of the Western market aiming at catering to the so called conscious consumers (Kuldova 2017). The ethical sell refers to any attempt at invoking ethical practices such as Fair Trade, eco-fashion and sustainability. The ethical sell also pinpoints the location where the political and cultural collide, while at the same time being deeply economic and profit-oriented (Kuldova 2017). This ethical sell is of course deeply unbalanced on a global scale, due to the fact that only a very limited amount of people able to afford this ethical fashion or even indulge in these eco-conscious concerns (Kuldova 2017). Therefore, ethical fashion has remained an elitist pastime and involves a certain marginalization. This is a particularly interesting development due to the fact that the materials involved in ethical fashion are 
not necessarily more expensive than their mass produced counterparts. Arna Lísa's shrug, for instance, has almost no material cost, but could still be marketed as an upscale fashion item with the according price. The ethical sell conundrum, therefore, serves as a reminder of the peculiarity of the fashion industry as a growing power in a capitalist society, where there is sometimes a huge gap between the fashionable and the marketable.

\section{Taste as a Marker of Class}

The dynamics of a capitalist society can be shown through the cultural taste people develop through certain subordination of the lower classes by tailoring their expectations and their view of themselves to their place in the hierarchy of social power and their share in this social product (Bourdieu 1984, 3). Bourdieu explains how the ideology of charisma would regard taste as an innate skill, but this is not the case as cultural needs always relate to social backgrounds, such as upbringing and education. The socially recognised hierarchy of the arts, therefore, corresponds to the social hierarchy of the consumers (Bourdieu 1984, 2). Taste functions as a marker of class. Then, what does ethical fashion tell us about the class of its consumers? In Arna Lísa's case, the institution she belongs to represents and caters to a certain class and its tastes, and thus also undoubtedly influences the artists' taste. Parsons School of Fashion and Design is also a certain marker of class and status being one of the top fashion schools in the US. It is also situated in New York, which still serves as a mecca of fashion and art. Bourdieu accounted for the agency of the social actors in developing taste, but also emphasised the sociological constraints that they operate within, whether they be institutional, historical or cultural. For instance, Arna Lísa expressed that she does not feel bound to her institution or others in her creative process, but recognises the underlying hold and influence Parsons and New York fashion has on her. She thereby becomes part of a certain class of actors by her association with her school, her city, her background and perhaps, more importantly, the connotations associated with being a fashion designer.

\section{Value and Social Media}

Creation and artistry have always been followed by self-promotion and marketing in order for the artist to be able to make a living out of the art and design. In the West, since the $18^{\text {th }}$ century, the emphasis has generally been on self-promotion and distribution (West 2014, 2). This has also been the case with Arna Lísa, as she sets out to distribute her work to the world. The greatest tool, according to Arna Lísa and many of her fellow designers and artists, is the application Instagram. Instagram, an app for sharing pictures with a short caption, is one of the most popular apps in the world. It is used by the public as well as companies and institutions. Instagram can, therefore, be the place where the artist gains representation and validation but does not serve as a marker of value in itself. For Arna Lísa, social media is also a tool for representation. However, it is also a source of great anxiety as the border between the artist and the designs becomes increasingly blurred. She expressed how some designers and artists become personas on social media in order to gain notoriety and representation. The artist can become the brand on Instagram and therefore self-commodify. This selfcommodification can take place in numerous ways. Some artists have accounts purely for business and do not showcase themselves as a person as much as an artist, while 
others use themselves to promote their designs as opposed to the other way around. This can come with negative impacts as well as the artist becomes a public figure or even 'insta-famous'. This often involves a certain re-invention of oneself as a marketable brand. Some even market themselves through the artistic lifestyle they lead and showcase themselves as more than their creations. Private and public companies are also on Instagram, and this can sometimes lead to employment and projects for artists and designers. Hence it can be both an important as well as a fickle tool for the artist. An artist or a designer is, of course, a certain title in itself that has many connotations. For Arna Lísa, the question remained whether she can live up to those connotations in order to brand herself, self-commodify in order to sell her designs or even gain employment.

\section{Fashion Design under Capitalism}

Arna Lísa thought about focusing on distributing her designs and her brand as an artist on Instagram, something that reveals the neoliberal tendencies of the current climate of the art and design world. According to Thet Shein Win and his article on analyzing marketing seminars for visual artists and art organizations, these neoliberal tendencies focus on the contemporary trend of the artist becoming an innovative entrepreneur (Win 2014, 2). The new entrepreneurial artists are expected to promote their projects and demonstrate a high level of professionalism in doing so as well as being extremely market savvy. This reflects a certain shift in capitalist modes and mirrors certain neoliberal tendencies, such as privatization, free trade and decreased social services (Win 2014 , 3). The artist becomes solely responsible for fundraising and promotion. This promotion also involves promotion of the artist as a brand and therefore certain selfcommodification. The artist has to become a brand, just as Arna Lísa had to become a persona on Instagram. This is, of course, additional labour for the artist and an interesting development in the creative industries. The concept of self-commodification is something deeply relevant to this aspect of self-promotion within the neoliberal market. A commodity gains its meaning through the systematic ways it is manufactured through certain ordered sequences of stages (Edensor 2005, 313). These stages are a stable set of places on an assembly line and ensure its production, marketing, display and sale. Self-commodification should work in the same way then, with fixed points on the assembly line. Social media is perhaps one of these fixed points to ensure production, marketing, display and sale of the artist and by extent the creative products the artist represents. Self-commodification, therefore, mirrors the neoliberal tendencies of the fashion industry and the capitalist tendencies that have become inherent to being an artist and making a living. Self-commodification is integral to the artist becoming a brand, while also being a source of anxiety and feeling of precariousness, and insecurity, typical of neoliberalism.

\section{Conclusion}

The creative industry here has been examined through Arna Lísa's experience as well as the object at hand, the shrug made of ethical, sustainable materials. Objects have a biography, a story, they show underlying power relations, social relations and important connotations. Arna Lísa's shrug is an extension of herself as an artist, a designer, as well as herself as a commodity, a brand. The shrug represents a certain side to the fashion industry and the institutions that have control and power in designing, distributing and validating. Fashion design is perhaps a certain collision between the market and creative 
design, aesthetics and practicality, the designer and the public. In her book, 7 Days in the Art World, Sarah Thornton describes how the art world is about experimenting and ideas but also about excellence and exclusion, and is in no way egalitarian or democratic (Thornton 1991, xii). The same can be said about the fashion industry, where the exclusion pertains to the lower classes in society, who cannot afford the fashionable, ethical designs and do not have the time and money to take part in concerns about sustainability and eco-fashion. Ethical fashion, therefore, becomes part of a capitalist, segmentary society as well as the designer, who tries to gain value and representation through social media and other neoliberal orientations.

Bourdieu, Pierre. 1984. Distinction: A Social Critique of the Judgement of Taste. Translated by Richard Nice. Cambridge: Harvard University Press.

Edensor, T. 2005. "Waste Matter: The Debris of Industrial Ruins and the Disordering of the Material World." Fournal of Material Culture. 10(3): 311-332.

Kuldova, Tereza. 2018. The 'Ethical Sell' in the Indian Luxury Fashion Business. In: Pouillard, Veronique \& Blaszczyk, Regina Lee (eds.) European Fashion: The Creation of a Global Industry, Manchester: Manchester University Press, pp. 239-258.

Thornton, Sarah. 1991. 7 Days in the Art World. New York/London: W. W. Norton \& Company.

Win, Thet Shein. 2014. "Marketing the Entrepreneurial Artist in the Innovation Age: Aesthetic Labor, Artisitc Subjectivity, and the Creative Industries." Anthropology of Work Review. 35: 2-13. 